\title{
Exploring the role of formal bodies of knowledge in defining a profession - The case of project management
}

\author{
P.W.G. Morris ${ }^{\text {a,* }}$, L. Crawford ${ }^{\text {b,c }}$, D. Hodgson ${ }^{d}$, M.M. Shepherd ${ }^{\text {e }}$, J. Thomas ${ }^{f}$ \\ ${ }^{a}$ School of Construction and Project Management, University College London, Gower Street, London WC1E 6BT, United Kingdom \\ ${ }^{\mathrm{b}}$ University of Technology, Sydney, P.O. Box 123, Broadway, NSW 2007, Australia \\ ${ }^{c}$ ESC Lille, Avenue Willy Brandt, 59777 Euralille, France \\ d Manchester Business School, Booth Street West, Manchester M15 6PB, United Kingdom \\ e International Project Management Association, 121 Harnham Road, Salisbury, Wiltshire SP2 8JT, United Kingdom \\ ${ }_{\mathrm{f}}$ School of Innovative Management, Athabasca University, 1 University Drive, Athabasca AB, Canada T9S $3 A 3$
}

\begin{abstract}
Since the mid 1970s, project management associations around the world have made serious attempts to conduct themselves as professional associations. Traditional professions distinguished themselves by emphasising standards such as service to the public and competence in their field, and by ensuring that their membership meets these standards. An important element of a profession is ownership of a body of knowledge that is distinctive to the professional group. Project management associations have spent considerable time and effort in developing Bodies of Knowledge (BOKs) and their associated certification programs, and indeed the popularity of these has been notable. Yet there are problems, some relating to the broader issue of whether the project management associations really are equipped to act as professional bodies, others related to the specific challenge of agreeing the 'distinctive body of knowledge' and to the value of certification.

This paper draws on insights from the rethinking project management EPSRC project as well as several separate research programs to explore the development of project management as a profession and the role of the formal BOKs in this professionalization, and to suggest a research agenda for critiquing, contributing to, and maintaining both the formal BOKs and the more general body of knowledge relevant to the needs of the discipline.
\end{abstract}

(C) 2006 Published by Elsevier Ltd and IPMA.

Keywords: Professionalism; Bodies of knowledge; Learning; Competency

\section{Introduction}

Recently the debate about the intellectual coherence of project management has achieved fresh prominence with many arguing, on the one hand, that the discipline, if such there is, is an amalgam of many other disparate disciplines [1-3], with others proposing that, despite this diversity there are nevertheless distinctive underlying threads organised not least by the developmental, 'unique' nature of the project life cycle $[1,4,5]$. Seemingly regardless of such academically nuanced uncertainty, practitioners have, since

\footnotetext{
${ }^{*}$ Corresponding author.

E-mail address: peter.morris@indeco.co.uk (P.W.G. Morris).
}

at least the late 1960s, appeared to be in no doubt that there is value in belonging to project management associations. The growth of the larger of such institutions has been quite phenomenal, the Project Management Institute for example having over 210,000 members as of March 2006. The primary service such associations provide was initially, and largely still is, to share information but from the $1980 \mathrm{~s}$ and 1990s onwards they began certifying 'project management professionals' (in their words) as meeting a required standard of knowledge, as outlined in their official 'Bodies of Knowledge'. The number of PMI 'project management professionals' in early 2006 was over 180,000 [6].

The issues this paper seeks to address are: (1) how do these associations stand as professional bodies; (2) how 
valid are their Bodies of Knowledge (BOKs) as descriptions of the relevant professional area of competence; (3) what is the significance of there being differing paradigms underlying the two or three principal BOKs in the field; (4) what is the potential role of research in contributing to these and related points?

The paper draws on the work of the rethinking project management EPSRC research network to suggest that: (a) currently project management is a 'semi-profession' or 'commercialized profession' [7] (b) bodies of knowledge are central to the perception of the discipline/profession, (c) the presence of differing underlying paradigms does not necessarily indicate a lack of maturity within the profession but does raise some issues of definition and application of appropriate practice, (d) project management associations should emphasize ways of developing competence other than merely following explicit knowledge guides such as formal BOKs, as traditionally have other professional bodies, and (e) although there are several different actors with vested interests in the bodies of knowledge, research has a real role in providing theoretically grounded, empirically-based evidence of the knowledge and wider aspects of competence - needed to manage projects successfully. We conclude by identifying a research agenda that we believe is appropriate for supporting and elaborating these assertions.

\section{The professions and knowledge - the case of project management}

The study of professionalization, or the path to professional status, involves consideration of both what a profession looks like (the traits) and the process by which these characteristics are attained (who does what and why).

Professions have long been studied in sociology as special ways of regulating work. Originally the interest was in identifying the characteristics that distinguished professions from non-professions [8,9] - typically the occupations cited are law, medicine, the church, architecture, engineering and accounting. This 'trait approach' identified the fundamental characteristics of professionalization $[10,11]$ as having:

- to meet formal educational and entry requirements,

- autonomy over the terms and conditions of practice,

- a code of ethics,

- a commitment to service ideals,

- a monopoly over a discrete body of knowledge and related skills.

Many doubt the possibility for any occupation in the contemporary context achieving the supposed autonomy and status of the traditional professions at their peak. The traits listed above reflect a model of a professionalism which is based on idealised, even romanticised, AngloSaxon notions of autonomy and authority which at best has applied to only a handful of occupations but which are no longer tenable [12]. The overwhelming majority of today's occupations achieve only some of these ideals and they have, as a consequence, been classified as 'semi-professions' [11,13], 'para-professions' or 'emerging professions.

Project management appears to fit into the 'semi-profession' or 'emerging profession' category [14], at least for the moment. Unlike the traditional professions, project management draws very little of its legitimacy by reference to its contribution to the public good, to an ideal of social service, or by adherence to an overarching ethical code. Some would argue therefore that project management is actually more a 'commercialized profession' $[7,15]$ as its claims to exclusive expertise are indexed primarily upon technical ability, managerial competency and in particular the delivery of economic benefits by the project manager for his or her client.

Instead of comparing semi-professions to ideal traits, it might be more fruitful to observe the processes of professionalization. From this perspective, claims to professional status must be placed in historical, economic, political, and social context and are seen as being fundamentally shaped by these conditions rather than assuming that claims to professional status are objective, inevitable, and timeless $[10,16]$. The development of the project management associations can be seen as part of this changing landscape.

Historically, professions begin with the recognition by people that they are doing something that is not covered by other professions [17] and where they then self-organise in order to control the supply of specialised or expert labour, both to guarantee a quality of service and to enhance the status of the professional him- or herself, often with the consent and support of the state [18] (as had been the case in the guilds - but the professions differentiated themselves from the guilds by the greater emphasis on knowledge and service, with an implication of class differentiation). The formation of a professional association thus very much depended upon the articulation of a distinctive 'competence territory' that members could claim as their exclusive area of practise [19].

Project management has followed a similar path. Project management's professional associations began being formed in the late 1960s/early 1970 s principally to facilitate the exchange of information, largely via conferences, seminars, journals and magazines. In the mid 1970s however PMI, the US based Project Management Institute, and later APM, the UK based Association for Project Management, embarked on programs to certify that people met their standards of distinctive knowledge. This required a reference work to be used as the basis of the certification tests. PMI established the first version of its (Guide to the) Body of Knowledge in 1976, although it was first published in 1983 [20]. Various other national project management associations produced their own versions, in some cases quite different from PMI's, over the next 10-15 years. A number of upgrades have followed since.

Clearly what we observe here are attempts by the project management professions to formulate the dimensions of the subject around which they can claim their 'distinctive 


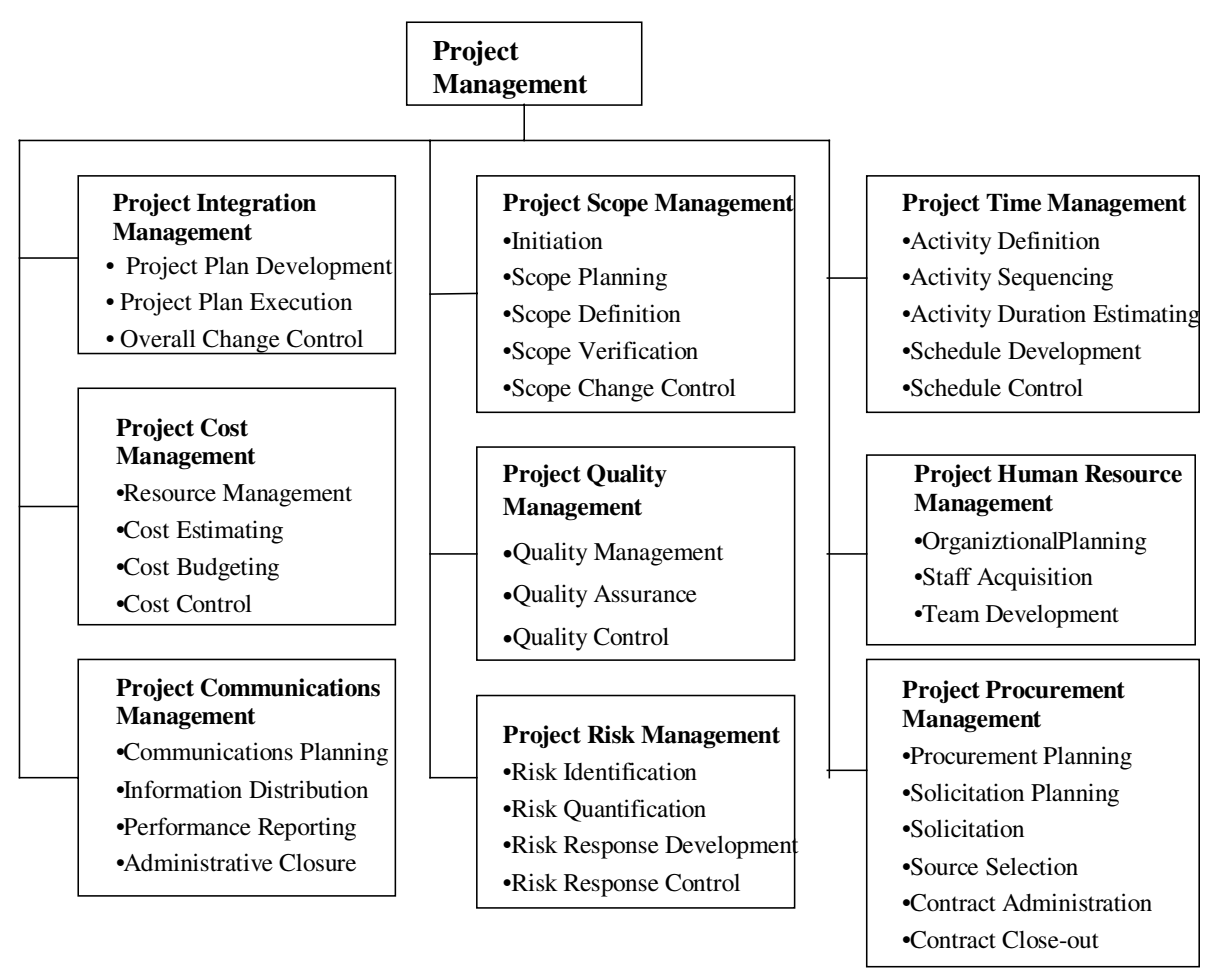

Fig. 1. The $P M B O K^{\circledR}$ Guide.

competence territory' (see Winter et al. in this Special Issue [4]; also [21,22]). In this sense we can see the project management BOKs as emergent knowledge frameworks and the project management associations acting as emerging professional bodies. Some may be doing so with quite overt pretensions to classic professional status - the UK's Association for Project Management for example has aspirations to achieving Royal Charter status. Others might be more ambivalent. But even if considered only as networks of practitioners [23], getting to grips with the knowledge area is obviously important. Communities of practitioners (and similarly, epistemic communities [24]) typically move to share and then define (reify) their knowledge base.
There are currently three formal project management 'Bodies of Knowledge': those promoted by PMI, by APM, and by the Japanese ENAA (Engineering Advancement Association of Japan) and JPMF (Japanese Project Management Forum). (The International Project Management Association has a "Competency Baseline" document [25] which amalgamates the British, French and German BOKs; the French and German BOKs are modelled closely on the $A P M B O K$ as, in consequence, is the IPMA structure.) The three are not inconsistent but the conceptual breadth - the scope - of each of these three, in our view, increases as one goes from PMI's $P M B O K^{\circledR}$ Guide [26] (Fig. 1) to the $A P M B O K$ [27] (Fig. 2) and then to the

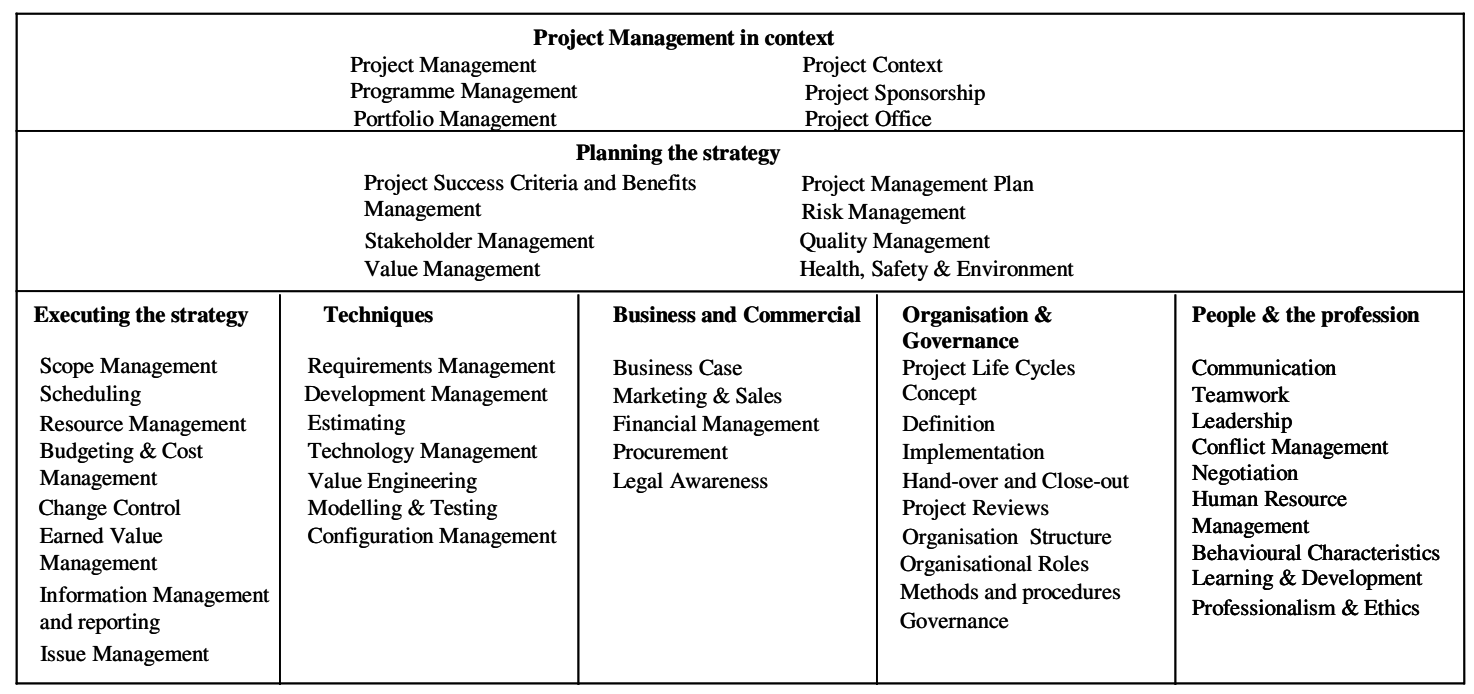

Fig. 2. The APM BOK. 


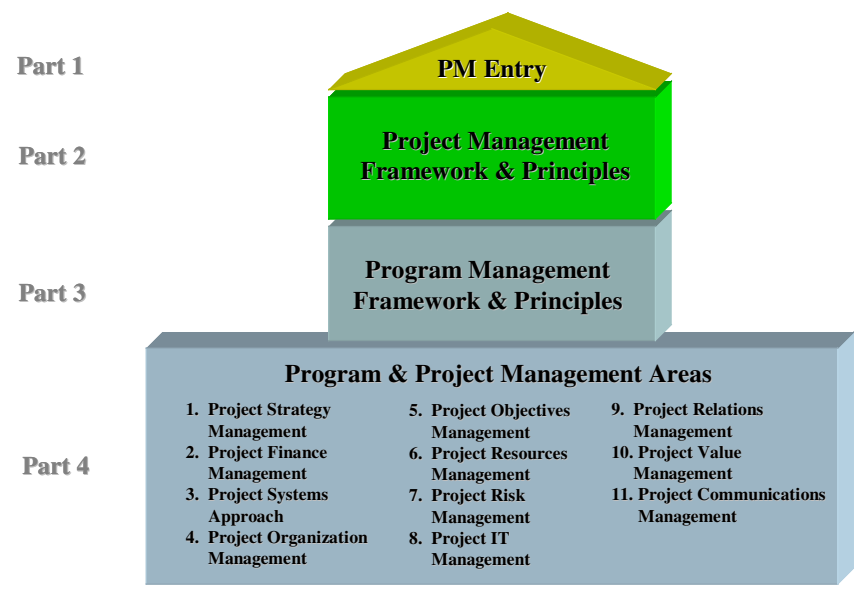

Fig. 3. P2M.

Japanese BOK, $P 2 M[28]$ (Fig. 3). The latter two, the $A P M$ $B O K$ and $P 2 M$, are much broader in conceptual breadth and scope than the $P M B O K^{\circledR}$ Guide.

While the project management associations have referred to their Bodies of Knowledge, so far at least, as the documents basically bearing that name which outline the knowledge elements that their members are supposed to be familiar with, in the more established professions the body of knowledge - small case, not initial caps - refers more generally to a recognized set of resources relevant to the activities within their field (e.g., $[29,30]^{1}$ ). It is not necessarily considered a 'best practise' source; this is often provided through a wider range of the professional association's activities (as with the Generally Accepted Accounting Principles in the US). And indeed with the wider range of resources now being offered by the project management associations - books, training, seminars, conferences, certification, and even, in the case of PMI's OPM3, maturity models [31]- project management is probably moving in the same direction.

Is a formal, explicit BOK for project management in fact a valid concept? Maybe, as we shall see, but only to a limited extent. Schön $[30,32]$ for example would argue that the nonrational, intuitive aspects of [project] management are typical of the professions, though these are rarely recognized explicitly in the bodies of knowledge [33] or, as we argue at the end of this paper, are given sufficient prominence in the associations' certification programs, despite their vital importance to the effective management of projects.

Projects are everywhere - cooking a meal could be considered as a project - and everywhere people are managing projects, more often than not without reference to any of the project management associations' bodies of knowledge. Unlike the traditional professions therefore project management is never going to be able to claim a monopoly over

\footnotetext{
${ }^{1}$ Hence from here onwards this paper uses both the initial capitalization form of 'Body of Knowledge' to represent the formal document the professional associations call by that title, and the lower case form of 'body of knowledge' to refer to the set of resources published by the associations to represent their collected resources representing guidance on knowledge in the field.
}

a discrete body of knowledge. In this sense too the project management associations are really more like semi-professions rather than traditional professions. Similarly they tend not quite to meet the other criteria: they do not have autonomy over terms and conditions of practice and though they have a code of ethics and most do require formal education and entry requirements these are less stringently exacting than in say law or medicine. Nevertheless, and perhaps precisely for this reason, certification has been cast in an important role as a means of endorsing the distinctiveness of the discipline (and hence the merits of the associations' members). How valid is this effort?

\section{The BOKs and certification in project management}

All the professional associations' formal BOKs were initially formulated, and have been maintained, largely in terms of their certification programs. Knowledge is one element of competency (others being skills and behaviours). Competency is an important trait of professionalism. The $\mathrm{BOK} /$ body of knowledge is central to the viability of the certification process.

The project management certification programs have been enormously successful. Why should this be the case, the Network asked, especially now when self-regulation by the professions is being widely criticized (as in accountancy and medicine for example)? One answer is that it provides status and recognition to many people in the field who value this. This may be particularly attractive for those who have not got a university qualification in project management (unlike their analogues in other professions), which is most of the associations' members. From the associations' viewpoint it is a highly effective means of attracting membership and increasing influence.

Has certification resulted in improved project outcomes? There has been next to no research in this area - one which is clearly central to the whole argument for the associations as professional bodies. Though Crawford [40] found no significant correlations between performance and standards, there is little research evidence to show that mastery of the 'discrete body of knowledge', the area of 'exclusive competence', leads to improved project performance. (Note: project performance, not project manager comportment.) To attempt to demonstrate such a relationship would raise serious methodological difficulties. ${ }^{2}$ Nevertheless, not to try

\footnotetext{
${ }^{2}$ We would need to distinguish between apprehension of formal project management knowledge and (1) project manager behaviour and doing the right things properly and (2) project outturn performance. We should also recognize that projects may not turn out well despite the application of appropriate knowledge, for example due to the actions of third parties or unforeseen circumstances. Formal knowledge of modern project management practices may not be essential for the effective management of projects; we shall argue later that skills and behaviours, tacit knowledge, reflection and judgment [72] are often just as important as formal knowledge. Various organizational characteristics will also significantly affect performance capability [76]. There is also the very great breadth of project types and conditions in which project management knowledge is to be applied [77].
} 
and do so is to avoid investigating what is for many an important premise on which project management certification and professionalism is built.

In fact, certification is only meant to be a recognition that a 'professional' has mastered the knowledge (and sometimes practice) requirements of the profession. In most professions, including medicine, certification does not guarantee performance - merely that the practitioner is acting within the strictures of accepted best practice and applying his or her discretion reasonably, in the judgement of fellow professionals. Hence, the Network felt, certification which indicates that an individual has internalised a body of knowledge could only ever be of limited value. Certification simply says that the person has done all that is required in terms of acquiring and demonstrating knowledge, and in many cases practice (even in nursing and teaching), and that, as a professional, one can rely on the certified person to act within the strictures of the profession and apply good professional judgment in the interests of the client or patient. It is the application of professional judgement, in terms of interpretation, insight, and discretion in practice which really sets the professional apart from the informed layperson or technical specialist.

Does the high visibility of the project management professional societies and their certification programs adequately explain the importance the discipline seems to attach to its formal Body(s) of Knowledge? After all, few if any other areas of management talk of having a body of knowledge and certainly not in such a pervasive way. (Though see Berry and Oakley [34] arguing for a BOK for management consulting, and Dean [35] for business ethics.) If we accept project management as a commercialised profession, a formal BOK plays a supplementary role in promoting the field.

The significance of the BOK in establishing the jurisdiction of a particular occupation should not be underestimated. A major current in studies of professionalism focuses upon the 'boundary work' which professions engage in [36-39] - the efforts made to establish their proprietary field of action, demarcationary efforts to exclude other occupations from acting within this field, and exclusionary strategies to regulate the supply of trained and able practitioners. Historically, the more established professions have been more successful here than have the semi-professions, such as librarians, nurses, and social workers - one might contrast the effective demarcation of mainstream medicine for example against the porous boundaries set up around, say, the occupation of teaching.

The biggest challenge for any occupational field engaged in professionalisation is deciding who to certify, at what levels and then who to license. Licensure is different from certification. Requiring a license to practice is a legal regulation recognizing the importance of controlling admission to the practice of this profession for the good of society. An important benefit of certification to the professions is that it helps recognize those who are eligible to be licensed. In any effort to build a licensed and recognized profession, there is a serious need to be able to certify knowledge.

Even from the viewpoint of the putative project management profession's defensive, differentiating, exclusive angle, it would be impractical, given the ubiquity of projects, and hence literally of people managing projects, to bar people from managing projects unless they are licensed. From a more promotional viewpoint however, one can foresee the threat of litigation over the failure to appoint someone to manage an important project who is not certified. There is evidence of this now beginning to happen, particularly in North America. Certification thus becomes an attempt to create barriers to entry and to promote the value of project management practitioners.

There is a large stream of research issues here: is project management a profession, a semi-profession, an emerging profession, a commercialized profession; what is the real role, and value, of certification; what is the implication for 'the right to practice'? What should the scope of the bodies of knowledge be? What evidence is there that professional certification has any value in ensuring competent performance or satisfactory project outcomes? And, as we shall see in the next sections, what place should empirical evidence have vis-à-vis the views of practitioners in formulating the BOKs; what paradigm what world view - of the discipline should the BOK reflect, and what should be the role of research in informing this view?

\section{The role of research in formulating the BOKs}

Much of the development work on the formal BOKs was carried out by practitioners based on "experience generally accepted for most projects most of the time" [26:3]. What has been the role of formal, empirically based research evidence in formulating such a critical element of the subject as its Body of Knowledge? What empirical evidence is there that the knowledge base used in the professional discipline is in fact valid and appropriate?

No formal program of research underlay the formation of the $P M B O K^{\circledR}$ Guide. Its structure has remained essentially unchanged (as arguably has much of its content) despite the huge volume of research published since the structure was initially fixed - much if not most of it on topics not covered by the Guide. ${ }^{3}$ (What does it take for this additional research-based knowledge to become 'generally accepted'?)

The $A P M B O K$ on the other hand has been more directly informed by research. The broader scope of the APM BOK was based explicitly on the success and failure

\footnotetext{
${ }^{3}$ See Crawford, who summarizes and adds to past surveys of project management topics covered in the leading project management journals [78]. The coverage is more about the management of projects - see below than the nine elements of the $P M B O K^{\circledR}$ Guide.
} 
research that lead to the management of projects para$\operatorname{digm}^{4}$ [41]. In addition the 4th edition of the BOK [42] was based on an extensive review of the literature [43] and survey of professionals' views on the knowledge considered necessary for professionals [44]. This exercise was repeated for the 5th edition in 2005 [45]..$^{5}$

$P 2 M$ was drafted by a committee under the leadership of Professor Ohara of Chiba University following a year long study funded by MITI. This study included a comprehensive review of existing standards and knowledge guides.

Research has thus so far played a modest role in the development and formalisation of the discipline as represented by the Bodies of Knowledge. Perhaps this is partly because at the time of formalising them research had a lower profile than it does today. It is now much more active - there are currently research events organised by PMI, IPMA, IRNOP, EURAM, and ProMac as well as some five research journals in the field. But in practice formal research still has a limited impact on the Bodies of Knowledge. Largely, we shall argue, this is because of the vested interests in the status quo; partly too it is because it is expensive to keep updating the complex certification infrastructure that the BOKs rely on [46,47]. (As a result, the professional associations seem less effective at capturing real learning than do the looser, less bureaucratically constrained Communities of Practice [48].)

An example of the limited effect of research on the BOKs is its minimal impact to date on their structures. Once set these have shown little flexibility in representing new knowledge. As we have just noted, PMBOK's structure has hardly changed since its inception. The recent revision of the fourth edition of the APMBOK recommended a modest change of structure but even this was rejected given the dislocation this would cause to the certification infrastructure. This illustrates nicely the issue of the place that empirically derived information and theoretically informed critique have in knowledge which is as socially owned as a project management association's BOK? As Morris et al. conclude à propos the failed attempt to modify the fourth

\footnotetext{
${ }^{4}$ The 'management of projects' paradigm is based largely around the now substantial evidence that many, though by no means all, of the factors causing projects not to be successful lie in front-end issues, externalities, technology, commercial matters and human behaviours $[5,79,80]$. Addressing these areas leads to a considerable broadening of the framework of knowledge that is considered relevant if one is to be competent in the overall discipline - in other words, a broadening of the knowledge areas - the topics - that would constitute an appropriate description of the domain. The 'Swedish school', using different terminology has also argued for a broadening out of the discipline $[81,82]$.

${ }^{5}$ Some caveats need to be noted however before any overwhelming claim for approval of this broader framework is made. Morris et al. contend that their questionnaire data, supporting the update of APM's 4th Edition BoK, shows that most APM topics were agreed as being needed by over $85 \%$ of their $450+$ respondents [45]. The questions can reasonably be asked however: (a) to what extent are respondents brainwashed by their national BOKs; and (b) is not it hard to say 'no: not needed' as opposed to 'more often needed' or 'more critically needed', neither of which were asked. And indeed, may not the Network, a largely, though not entirely, UK group, itself be brainwashed by the APM BOK framework?
}

edition BOK structure: "Because management knowledge - particularly in practice-based areas like project management - is situated, its legitimacy is derived through its group endorsement. [This raises] very real questions of ... how representative and valid is the data that is drawn on to write the BOK; if it is owned by a group, who is elected to represent the profession's group owning and writing the BOK?" [45]. From a socially constructed view of knowledge, one cannot avoid reflecting on the power relations $[49,50]$ associated with the different actors at play $[51,52]$. A more 'critical' interpretation of project management knowledge may therefore be appropriate [53].

\section{Key actors vis-à-vis the bodies of knowledge}

Threaded throughout the Network discussions were conversations around the roles of the various participants involved in the development of project management [37,53] discourse and the influence of these participants on the future of project management. First there are the professional associations themselves.

\subsection{Professional associations}

Their strength and influence varies hugely. PMI is very strong but, as we saw earlier, is not a professional body in the traditional sense. APM does not have the international strength of PMI but is locally influential; it may be seeking a more traditional professional role than PMI and follows PMI in influence. Most of the other national associations, as represented by the members of IPMA, the International Association of Project Management, are comparatively weak. The associations coordinate the creation of the formal BOKs, register education providers, sponsor conferences for information dissemination, and fund research - the traditional role in fact of professional bodies. But a major, and surely regrettable, result of their efforts has been the standardization - even commodification - of project management discussed below [54]. Professional associations' certification initiatives drive this process, but so far the associations have not initiated or enforced the standards that are necessary in traditional professionalization. In fact, it is questionable whether they have the authority to enforce such standards without licensing from government bodies, which most have been reluctant to pursue.

The main outcome of the professional associations' development of their formal Bodies of Knowledge and certification programs has been an increase in the number of participants in this knowledge industry (which can be seen not only in the increasing number of members or certified practitioners but also in the increasing number of academics, gurus, consultants, trainers, etc). Maintaining control over the BOK certification processes is central to maintaining their position in the industry. However, as member-driven organizations, the question of who is driving the development of the Bodies of Knowledge and training 
and certification is, as we have noted, not clear. Examining public records from PMI on the volunteers on standards committees or on the volunteer leadership of the organizations suggests that Registered Education Providers and consultants seem to be a large component of the volunteer administration of the organization.

\subsection{Consultants}

The consultant's primary function is to convert abstracted managerial knowledge into a saleable and applicable form. This often involves transferring the knowledge into a simplified form which can be readily comprehended, generalized to a variety of disparate contexts, and moved easily throughout large organizations. By producing simple and generic models with clear value propositions, consultants have increased the demand for all aspects of project management.

But having invested in the development of these models, based on an existing Body of Knowledge, many consultants will resist the additional investment needed to change training materials, consulting tools, value models, etc., to accommodate changes to the BOK. Thus, in some ways, consultants are responsible for the 'dumbing down' of project management Bodies of Knowledge, the spread of BOK models across organizations, and the resistance to changing BOKs.

\subsection{Gurus}

Gurus come from many arenas (consulting, training, academia, practice) and serve the primary function of translating managerial knowledge into practice forms that can be understood and used by practitioners, consultants and trainers. Gurus also legitimize certain types of managerial practices by translating them into the mainstream business press, presenting these ideas at practitioner and academic conferences, and promoting such practices through their own consulting firms.

Improving the standing of project management to that of a profession is likely to improve the status of the gurus and the currency of their published work. Having their concepts, models or definitions included in the Bodies of Knowledge provides added leverage and profile for these individuals.

\subsection{Consumers}

Consumers are a poorly understood component in the field. There is clearly a strong (and intensifying) demand amongst consumers for knowledge products, yet there is an obvious skepticism, amongst primary consumers, about the validity and quality of the knowledge products they consume [55].

Large multinational enterprises represent the largest consumers of consulting services and training around standardization and certification of project management. These consumers are interested in professionalization because they believe it will improve the practice of project management and their project delivery capability.

Individual project manager consumers are interested in developing their skills and improving their performance. Many believe that professionalization is fundamental to improving their authority and thus their ability to deliver successful projects. Once certificated a project manager may well be motivated to resist changes to the relevant BOK if this would make his or her certification out of date. The professions' focus on updating qualifications, lifelong learning and recognition that information, standards, knowledge, or skills go out of date often makes little impression: many certified project managers appear to believe that a basic knowledge of foundation level project management knowledge groups is sufficient.

\subsection{Academics and researchers}

Engineering and business schools serve two primary and related functions in this knowledge field. First, they traditionally perform a quality control role in assessing the project management practices in use [56]. Examining and critiquing practice through research ought to act as a conscience call to the other actors and should add to the bodies of knowledge. Academics are interested in the study and development of a professional body of knowledge as an academic exercise in it own right. Whether these critiques and extensions of research make it into the bodies of knowledge is largely dependent on how widespread the results of such studies are published and how well they resonate.

A second role is to actively participate in the control of the required educational process and, therefore, the trainee. Through such control, educators will be able to participate in the definition of project management and the role of the project manager, and the development of legitimate entry barriers. Given the current levels of demand for project management 'education', based in many instances around the formal BOK knowledge areas and professional accreditation [sic], there is serious pressure for educational institutions to incorporate the BOKs into their curriculum.

Clearly, all the key players have vested interests in the formal Bodies of Knowledge and how they are used. Equally clearly, when a BOK is revised, some of these players may lose some advantage while others will gain, depending on the path that professionalization takes. Zwerman, Thomas, Haydt, Williams [39] put it this way: "If the professional bodies dominate the process, they may be able to dictate to the consultants and academics at a level that is not healthy for the development of the discipline. At the same time, if the consultants dominate the professionalization process, the short-term profit drive will be difficult to coexist with some of the professional values that need to be enforced. Individual accountability of project managers may be a serious win for corporations, but a serious loss for consultants and individual project managers." 
At their best, researchers - as opposed to the broader categorization of academics, who may have substantial vested interests in teaching income - have a major role to play in trying to ensure objectivity; in asking the hard questions. Two areas that the Network saw as critical in the current project management professional landscape are (1) what should be the appropriate scope of the discipline, and (2) how 'mechanistically' should recommended practices be viewed and applied?

\subsection{Research implications of the BOK paradigms}

Turner recently referred to the fractal nature of project management (as the term is currently defined). This is perfectly captured in PMI's $P M B O K^{\circledR}$ Guide with its nine knowledge areas and five process groups (initiating, planning, executing, monitoring and controlling and closing) and the prevalence of project process life cycle concept. The theory is that this sequence will get you from one stage of a project to another (one stage-gate/milestone to another), which is indeed proper practice in the stage-gate process now commonly adopted as good governance practice [57]. It is however quite a different view of the discipline from one which emphasises the issues that need managing as the product evolves through its development cycle. This is the 'management of projects' perspective upon which the APM BOK is based. Both views, the Network believed, are valid, but both need to operate together. The $P M B O K^{\circledR}$ Guide, as we have seen, is quiet on the broader implications of the management of projects perspective; we shall discuss in a moment the research implications of this.

The $P M B O K^{\circledR}$ Guide reflects a strong execution orientation, having hardly any material on strategy and project definition, the management of external factors, or human behaviours [58]. The PMBOK view of the discipline has become extremely pervasive, so much so that many people in many organisations do not see project management as the discipline of managing projects but as the discipline of delivering a project 'on time, in budget, to scope', leaving it to other disciplines to deal with the establishment of these targets. In fact, as we shall shortly see, the management of the front-end is absolutely key to how delivery is executed.

The Guide's conception of project management is understandable when one considers its historical context but the limited paradigm of the discipline created by its structure does present issues. Historically, the project management associations emerged in the late 1960s and 1970s very much in relation to execution issues, primarily for work which was largely defined by contracts. The larger 'whole project' perspective in which the US Air Force (Atlas), Navy (Polaris), and NASA (Apollo) pioneered the discipline in the 1950s and 1960s was largely ignored $[21,59]$. PMI has grown since these early days to encompass a wide range of project types and an increasing interest in the management of multiple projects and programs and in the enterprise wide management of projects, as is evidenced in its new 'standards' for program and portfolio management and organisational project management maturity [31]. Yet all these standards still reflect the original PMBOK configuration - the same initiating, planning, executing, monitoring and controlling and closing sequence, nine knowledge area structure of the Guide - a foundation which is not common in much of the literature in this broader field.

In fact, the $P M B O K^{\circledR}$ Guide and many of PMI's standards generally do not, in the Network's view, adequately reflect the research literature, either in scope of topics covered or in substantive detail rendered. It is important therefore for the research community to continue to critique the limitations implied by these standards. If they remain unchallenged the discipline (the profession) risks being defined by models which ignore areas that are critical to achieving satisfactory outcomes. As a result, project management may at best sometimes be ineffective, or at worst downright wrong $[14,22,45]$. For the Network therefore a rather urgent issue is to examine the consequences to the discipline of the way the formal Bodies of Knowledge are defined.

The front-end is a crucial instance. The way the project front-end is managed has a disproportionately large influence on the project outcome $[21,58,60,61]$. Should project management as a discipline cover the management of the front-end or is it limited to the execution phases, as PMBOK and many organisations now seem to imply? We need to understand better, the Network felt, the role of management and governance in moving the evolving project definition through the development cycle, the linkage with enterprise strategy, value and effectiveness [4], and the management of exogenous factors and stakeholders [61]. These areas influence the ultimate value of the project, can seriously impact delivery efficiency and effectiveness, and, insofar as they define the delivery targets, the metrics by which project delivery will be judged. The implications to the way the discipline is perceived are extremely important. For if project management is seen as really being concerned primarily just with delivery efficiency then disciplines other than project management must be responsible for the management of front-end issues - development management or systems management for example. Are we happy to be saying that project management does not (or should not) manage perhaps the most critical parts of the project?

There is also need for greater clarity on project management's relation with portfolio and program management. Program management in particular is not well-grounded evidentially. (Indeed, are there separate disciplines or do we not need a more comprehensive view of the over-arching domain?) There are conflicting perceptions of the core features of program management. An execution paradigm of project management encourages program management to be contrasted as a more strategic discipline than project management. There is a view current, for example, that project management is about outputs whereas program management is about outcomes [62]. This surely needs challenging: most major companies see projects as producing outcomes as well as outputs (production throughput, 
therapeutic behaviour, meeting systems and business requirements, as well as commercial and financial goals). Program management is more strategic than project management, but to deny the discipline of project management a strategic, holistic role is surely dangerous, ill-grounded, unnecessary, and limits the membership of project management associations and project manager roles to the more junior practitioner level leaving senior practitioners without a professional home. Project Managers, Program Managers, Project Sponsors, Portfolio Managers, Project Directors, Project Services Managers, etc. are, in the Network's view, all members of a project management 'job family' sharing a responsibility for the 'management of projects'.

Part of the problem is that the process for writing standards typically reflects practice as it is now, rather than as someone thinks (or research suggests) it ought to be. Standards are written essentially by practitioners, as we have seen. If the practitioners are largely lower level project managers, or they lack the broader perspective available either through experience or education, then they will constrain the scope of the project management paradigm to their current execution perspective, saying they have no control over strategy and can get no experience in it and that therefore these broader, more strategic topics should not be a part of the profession's standards (and if included, might limit their ability to be certified). As in the front-end instance, the effect is that Project Managers are excluded from the most critical parts of the project, leaving these to other members of the project management job family. Failure to see the bigger picture becomes dangerous if the subdivisions are not effectively integrated and the things that really need managing are not adequately addressed.

Much of the confusion is semantic - it comes from the way terms are defined. Hence for example, if project management is defined using the $P M B O K^{\circledR}$ Guide paradigm then it is not particularly surprising that senior managers are reported as thinking that project managers should not be involved in strategic issues or project definition, or procurement, as research by Crawford for example recently reported [40]. Nor, as Thomas et al. [63] found, that in adopting the $P M B O K^{\circledR}$ Guide view of project management senior managers see project management pre-eminently tactical and efficiency oriented and insufficiently focussed on creating and delivering value.

Schön argues that competing paradigms are healthy in a practice-based profession such as management [30]; that a mature discipline is one which allows space for differences of opinion and views about even quite fundamental matters. Management, and project management, deal with a huge range of socio-technical contexts. The search for an authoritative, unitary position on all matters relating to projects may thus be a symptom of immaturity. There is, for example, a single rather large and growing body of knowledge called medicine from which springs a large number of 'professions' or semi-professions including all specialisations of medicine, nursing, counselling etc. There are many in project management who seek unity of standards and certifica- tion, even at a global level, but perhaps doing so before we develop a better understanding of the boundaries and requirements of the profession would be premature. (It may even be of limited value given the breadth of contexts to which single certification would apply.)

Research has a major role in challenging, shaping and populating such standards. And given the current activity in generating new standards, and upgrading existing ones, ${ }^{6}$ the timing is highly appropriate.

Epistemologically, the more tightly defined scope of the $P_{M B O K^{\circledR}}$ Guide might seem more accessible than the broader range of the $A P M B O K$ and $P 2 M$. The breadth of issues involved in covering the development, as well as delivery, of projects in terms of a broader range of valueoriented criteria creates additional research challenges. Multiple players become involved, drawing on multiple theoretical bases and methodological approaches. Different research methodologies can lead to different results. The broader framework means that we need to consider carefully the appropriateness of the research methodology to the issue being investigated and that the generalisation of recommended practice from the empirical data is really justified [64]. As Griseri notes, "whilst there are few if any laws of management, there are lots of theories. The most important feature of this proliferation ... is their lack of evidential support - few published studies in management have very sound methodologies" [65:43]. How secure are we on the validity of the knowledge - the area of distinctive competence - that the $\mathrm{BOK}$ is purporting to represent?

As Winter et al. summarise in this Special Issue, for the Network the broader management of projects perspective requires a more interpretivist approach to addressing the multiple complexities that participants typically experience in being associated with a project.

\subsection{Interpretation versus prescription}

There is a natural tendency to read the BOKs as implying best practices. Best practice is itself an arguable concept, particularly when divorced from context $[65,66]$. Given the range of project types [67,68], we should expect a wide variation in the range of project management competences, and approaches, that may be required. The challenge for the professional associations in establishing their Bodies of Knowledge is to set out the jurisdiction for pro-

\footnotetext{
${ }^{6}$ APM plans to update its new 5th edition BOK before long. PMI plans to do the same for OPM3 and its new Program and Portfolio Management standards. Also BS6079 is currently being upgraded. Reference to BS6079 gives rise to two points: one, there is no direct research input; two, the ISO and BSI standards have not been referred to in this paper since we are really addressing the professional associations and their bodies of knowledge. PMI is however again an interesting case. PMI always refer to their major publications such as the $P M B O K^{\circledR}$ Guide and $O P M 3$ as standards irrespective of their formal status. ANSI, the American National Standards Institute, regards PMI as a 'standard writing body'; this allows some of PMI's output to be regarded as 'a standard' in the USA. Most standard setting bodies outside the USA however do not regard any of PMI's outputs as formal 'standards'.
} 
ject management without implying that there is 'one best way' to manage regardless of context and contingency; and to promote and disseminate this knowledge in a manner which allows intelligent and reflexive practitioners to use their professional discretion to choose how to relate to and engage the principles, concepts, models, and techniques it contains.

The $P M B O K^{\circledR}$ Guide, and the new PMI standards on Program Management and Portfolio Management, seem to promote on a more mechanistic model, for example emphasizing the principles of job fragmentation and bureaucratic control. While this may be appropriate for certain situations - the more routine [69] or technical [70] - it may be quite inappropriate to many others, for example in the front-end $[23,53]$. If applied too literally, as it often is, it runs counter to many of the developments in management over the last thirty years which have emphasized softer control mechanisms, and which have encouraged instead empowerment, integrated tasks, and enhanced autonomy and discretion in work design. It is a model more suited to achieving security of execution rather than the shaping of effective solutions. Important though this is, other characteristics and competencies are sometimes required. Research needs to reflect the reality that managing projects often both requires imagination and conception - delivering the "future perfect" [71]. It is also often very difficult. Many interrelated factors may need addressing; decisions are often complex and require considerable judgment and experience. Simplistic solutions may be appropriate for defined, stable work packages, but rarely for the more complex management of the overall project [36].

Codified knowledge, as presented in the formal Bodies of Knowledge, has its limitations in an area like this. The epistemology of a practice-based area such as management emphasizes reflection on and for 'doing' [30,72]; the value of 'knowing' derived as action as opposed to being looked up in codified, explicit forms [73]. Hence the importance the professions give to learning 'on the job': historically the traditional professions all consistently mixed formal learning with some form of apprenticeship [74]. The Network thus stressed the importance of 'know-how' in project management, as well as 'know-what'. Project management, the Network concluded, is as much about craft knowledge as codified knowledge - tacit as explicit. In short, that a broader, more interpretivist view of the discipline is needed, one which contextualises and extends the discipline across the whole 'management of projects' job family, rather than one which is predominantly prescriptive.

Some would even argue that professional status and influence relies upon the opposite of too clear an explicit, didactic BOK - that professionalization relies upon the "deliberate creation of an aura of indetermination about their activities that denies the possibility of rationalization and codification" [75:697]. Project management associations may run the risk of undermining their claims to professionalism if they imply that project management expertise can be codified as methodologies with an unspec- ified role reserved for practitioner insight and discretion. Recent research exploring the fundamental assumptions embedded in the $P M B O K^{\circledR}$ Guide and the elaborations necessary for skillful practitioners to successfully manage projects provides evidence of these challenges [33].

\section{Conclusions}

The professions are defined largely around their area of distinctive competence. The project management BOKs are an attempt to map out the knowledge elements of this competence.

Project management BOKs are clearly important. Practitioners have a strong interest in them since such 'standards' - which is de facto what they essentially become - influence industry views on competence, best practice, and training and development. And they are of interest to academics since any such attempt to define the 'discrete body of knowledge and related skills' raises questions about the validity of the knowledge base in the subject being discussed or taught, both in epistemological terms and in terms of what is deemed to be covered by the subject area.

Drafting a formal Body of Knowledge brings with it risks. Not least are those of scope and relevance; not recognising the real scope of the discipline can lead, as we have seen, to misperceptions on a significant scale. Overemphasis on didactic methodology suggesting the rote application of best practices diminishes the role of judgement that managers need in applying knowledge in different contexts. The subject requires a more interpretivist approach, particularly with respect to the broader, more strategic elements of knowledge which feature at the more front-end, senior, and program levels of the 'management of projects' job family. Positioning the profession, and its bodies of knowledge, in this bigger domain, is the challenge now in rethinking - and re-casting - project management.

Research has an important role to play in this re-positioning. Though the dimensions of the profession have, so far, largely been driven by practitioners, researchers should have the advantage of time, data and argument. They teach. They influence. They serve on the professions' panels. The time is ripe for a more systematic input from the academic research community, not least to address the points articulated in this paper.

If we rely on the project management associations to tell the academics what to think and teach, instead of having research test the concepts theoretically and the issues practically, we get into self-fulfilling prophecies. We may be in some danger of that now.

Several lines of research have been identified:

- What do the traits of project management as a profession, semi-profession or a commercial profession signify to the different actors involved? How important are the attributes of traditional professionalism that project management would seem to be missing? How serious is this loss? What, if anything, should be done to fill the gaps? 
- If project management is an emerging profession, how happy are we with the trajectory it is on? Is the way PMI is shaping its evolving standards for program and portfolio management, and for maturity, satisfactory? (Indeed, is maturity a sound concept as articulated in such a broad subject as the management of projects, or 'enterprise management'.) What about the other professional associations' models? What contribution can well designed and executed research make to such questions to bring clarity and objectivity and reduce the polemical tendency?

- What are the consequences to the discipline of it having differing BOK paradigms (scopes)? What can be done to make them more aligned?

- What is the proper place of certification in the development of project management as a profession? Should we be investigating the value of certification more systematically? (Are the professional associations testing the wrong elements of knowledge/competency?)

- What should be the role of research in defining preferred practice and contributing to the formal BOKs and the wider bodies of knowledge? What is the appropriateness of best practice methodologies in a subject as influenced by context, interpretation, tacit and group knowledge?

- What are the implications of professional associations accrediting universities to teach project management based on the established BOKs without concern for practical or research interests in the field?

Such research could make a major contribution to the development of the discipline. The result would be a better understanding of the nature and limitations of the knowledge element in project management professional competence; more informed content; and a better understanding of professional development and of the value of certification. Maybe, above all, there would be a growing realisation that we are really all talking about the same discipline, albeit often, and necessarily, in different ways.

\section{References}

[1] Turner JR. Editorial. Int J Project Manage 2006;24(2):46.

[2] Koskela L, Howell G. The underlying theory of project management is obsolete. In: Slevin DP, Cleland David I, Pinto JK, editors. Project management research at the turn of the millenium. In: Proc of PMI Res Conf, July 2002. Seattle, Newtown Square, PA: Project Management Institute; 2002. p. 293-301.

[3] Shenhar AJ. Project management theory: the road to better practice, In: Proc of the 27th Annual Seminar/Symp, Boston, MA: October 7-9, 1996, Upper Darby, PA: Project Management Institute, 1996.

[4] Winter M, Smith C, Morris PWG, and Cicmil S. Directions for future research in project management: the main findings of the EPSRC Research Network. Int J Project Manage 2006, special issue.

[5] Morris PWG, Pinto JK. The Wiley guide to managing projects. Hoboken, NJ: John Wiley and Sons; 2004.

[6] Project Management Institute. Fact Sheet March 2006 [Web Page]. Available from: http://www.pmi.org/prod/groups/public/documents/ info/gmc_memberfactsheetmar06.pdf, 2006. (Accessed on 14 March 2006.)
[7] Hanlon G. Professionalism as enterprise: service class politics and the redefinition of professionalism. Sociology 1998;32(1):43-63.

[8] Glazer N. Schools of minor professions. Minerva 1974;12:346-64.

[9] Moore W. The professions. New York: Sage Foundation; 1970.

[10] Roach Anleu SL. The professionalisation of social work? A case study of three organisational settings. Sociology 1992;26:23-43.

[11] Hugman R. Professionalization in social work: The challenge of diversity. Int Social Work 1996;39:131-47.

[12] Evetts J. New directions in state and international professional occupations: discretionary decision making and acquired regulation. Work Employment Soc 2002;16(2):341-53.

[13] Etzioni A. The semi-professions and their organization: Teachers, nurses, social workers. New York: The Free Press; 1969.

[14] Zwerman B, Thomas J. Potential barriers on the road to professionalization. PM Network 2001;15(5062).

[15] Hodgson DE. The new professionals; professionalisation and the struggle for occupational control in the field of project management; In: Muzio, D., Ackroyd, S., Chanlat, J.F., (Eds.), Redirections in the Study of Expert Labour: Medicine, Law and Management Consultancy, Basingstoke: Palgrave, 2007.

[16] Hugman R. Organization and professionalism: The social work agenda in the 1990s. Br J Social Work 1991;21:199-216.

[17] Abbott A. The system of professions. Chicago: The University of Chicago Press; 1988.

[18] Larson SM. The rise of professionalism. Berkeley, CA: University of California Press; 1977.

[19] Eraut M. Developing professional knowledge and competence. London: The Falmer Press; 1994.

[20] Crawford LH. Global body of project management knowledge and standards. In: Morris PWG, Pinto JK, editors. The Wiley guide to managing projects. Hoboken, NJ: John Wiley and Sons; 2004.

[21] Morris PWG. The management of projects. London: Thomas Telford; 1994.

[22] Morris PWG. The (Ir)relevance of project management. In: Proceedings of International Association for Project Management world congress, June. Moscow, Zurich: IPMA; 2003. p. 3.

[23] Wenger E. Communities of practice: learning, meaning and identity. Cambridge, UK: Cambridge University Press; 1997.

[24] Haas P. Introduction: epistemic communities and international policy coordination. International Organization 46 (1):1-35.

[25] Caupin G, Knopfel H, Morris P, Motzel E, Pannenbacker O. ICB IPMA Competence Baseline. International Project Management Association; 1999.

[26] Project Management Institute A Guide to the Project Management Body of Knowledge (3rd edition), Newtown Square, PA: Project Management Institute; 2004.

[27] Association for Project Management Body of Knowledge (5th edition), High Wycombe: APM, 2006.

[28] ENAA P2M: A guidebook of project and program management for enterprise innovation: Summary translation. Japan: Project Management Professionals Certification Center (PMCC), 2002.

[29] Danziger K. Constructing the subject: Historical origins of psychological research. Cambridge: Cambridge University Press; 1990.

[30] Schön DA. The reflective turn: case studies in and on educational practice. New York: Teacher's College Press; 1991.

[31] Project Management Institute Organizational Project Management Maturity Model: Knowledge Foundation, Newtown Square, PA: Project Management Institute, Inc., 2003.

[32] Schön DA. The reflective practitioner: How professionals think in action. Aldershot: Ashgate Publishing Ltd; 1983.

[33] Buckle P, Thomas J. Deconstructing project management: a gender analysis of project management guidelines. Int $\mathbf{J}$ Project Manage 2003;21(6):433

[34] Berry A, Oakley K. Consultancies: Agents of organizational development: Part II. Leadership Organization Dev J 1994;15(1): $13-21$.

[35] Dean PJ. Examining the profession and the practice of business ethics. J Business Ethics 1997;16(15):1637-49. 
[36] Larkin G. Occupational monopoly and modern medicine. London: Tavistock; 1983.

[37] Schein, E. Professional education, New York: McGraw Hill,

[38] Williams TM. Assessing and building on project management theory in the light of badly over-run projects. IEEE Trans Eng Manage 2005;52(4):497-508.

[39] Zwerman B, Thomas J, Haydt S, Williams TM. Professionalization of project management: exploring the past to map the future. Newtown Square, PA: PMI; 2004.

[40] Crawford LH. Senior Management Perceptions of Project Management Competence. Int J Project Manage 2005;23(1):7-16.

[41] Morris PWG, Hough GH. The anatomy of major projects. Chichester: John Wiley and Sons; 1993.

[42] Dixon M, editor. APM Project Management Body of Knowledge. Peterborough, England: Association for Project Management; 2000.

[43] Themistocleous G, Wearne SH. Project management topic coverage in journals. Int J Project Manage 2000;18(1):7-11.

[44] Morris PWG. Updating the project management bodies of knowledge. Project Manage J 2001;32(3):21-30.

[45] Morris PWG, Jamieson A. Shepherd MM. Research updating the APM Body of Knowledge 4th ed. Int J Project Manage 2006;24:46173.

[46] Bowker GC, Star SL. Sorting things out: Classification and its consequences. Cambridge, MA: MIT Press; 1999.

[47] Brunsson N, Jacobsson B. and Associates. A world of standards, Oxford: Oxford University Press, 2000.

[48] Amin A, Cohendet P. Organisational learning and governance through embedded practice. J Manage Governance 2000;4:93-116.

[49] Foucault M. Power/Knowledge: selected interviews and other writings, 1972-1977. Brighton: Harvester; 1980.

[50] Thompson M. Structural and epistemic parameters in communities of practice. Organization Sci 2005;16(2):151-64.

[51] Latour B. Pandora's hope: Essays on the reality of science studies. Cambridge, MA: Harvard University Press; 1999.

[52] Law J, Hassard J. Actor network theory and after. Oxford, UK: Blackwell; 1999.

[53] Hodgson D, Cicmil SJK. Making projects critical. Basingstoke: Palgrave; 2006.

[54] Hodgson DE, Cicmil SJK. The politics of standards in modern management: making 'the project' a reality. J Manage Studies 2007 (forthcoming).

[55] Thomas J, Delisle C, Jugdev K. Selling project management to senior executives: framing the moves that matter. Newtown Square, PA: Project Management Institute; 2002.

[56] Barley SR, Meyer G, Gash D. Cultures of culture: Academics, practitioners, and the pragmatics of normative control. Administrative Sci Quart 1988;33:24-60.

[57] Association for Project Management Directing Change. A guide to governance of project management, High Wycombe, UK: Association for Project Management, 2004.

[58] Morris PWG. Managing the Front-End: how project managers shape business strategy and manage project definition. In: Proc of the 2005 Project Management Institute EMEA Symp. Edinburgh, Newtown Square, PA: Project Management Institute; 2005.

[59] Stretton A. A short history of project management: part one: the 1950s and 60s. The Australian Project Manager 1994;14(1):36-7.

[60] Flyvbjerg B, Bruzelius N, Rothengatter W. Megaprojects and risk: an anatomy of ambition. Cambridge: Cambridge University Press; 2003.
[61] Miller R, Lessard DR. The strategic management of large engineering projects: shaping institutions, risks and governance. Cambridge, MA: The MIT Press; 2001.

[62] Office of Government Commerce Managing successful programmes. Norwich, UK: The Stationery Office, 2002.

[63] Thomas J. Problematizing project management. In: Hodgson D, Cicmil S, editors. Making projects critical. London: Palgrave; 2006.

[64] Smyth H, Morris PWG. An epistemological evaluation of project and project management research. Int J Project Manage (forthcoming).

[65] Griseri P. Management knowledge: a critical view. London: Palgrave; 2002.

[66] Leseure, Michel, Birdi, Kamal, Bauer, Joachim, Denyer, David, Neely, Andy. Making Best Practice Stick: How UK firms can increase productivity by adopting leading-edge working practices [Web Page]. Available from: http://www.aimresearch.org/publications/ 010705bestpracticereport (Accessed on 10 June 2006).

[67] Crawford LH, Hobbs JB, Turner JR. Project categorization systems and their use in organisations: An empirical study. In: Slevin DP, Cleland David I, Pinto JK, editors. Innovations: Project Management Research 2004. Newtown Square, Pennsylvania: Project Management Institute Inc; 2004. p. 65-81.

[68] Shenhar AJ, Dvir D. Toward a typological theory of project management. Res Policy 1996;25:607-32.

[69] Burns T, Stalker G. The Management of Innovation. London: Tavistock Press; 1961.

[70] Nilsson M. Learning, frames, and environmental policy integration: the case of energy policy in Sweden. Environ Plan 2005;23(2):207-26.

[71] Pitsis T, Clegg S, Marosszeky M, et al. Making the future perfect: constructing the Olympic dream. In: Hodgson D, Cicmil S, editors. Making Projects Critical. London: Palgrave; 2006.

[72] Argyris CSDA. Organisational learning: A theory of action perspective. Reading, MA: Addison-Wesley; 1978.

[73] Cook SDN, Seely Brown J. Bridging epistemologies: the generative dance between organizational knowledge and organizational knowing. Organization Sci 1999;10(4):381-400.

[74] Handy C. Myself and other important matters. Oxford: ButterworthHeinnemann; 2006.

[75] Boreham P. Indetermination: Professional knowledge, organization and control. The Sociol Rev 1983;31(4):693-718.

[76] Davies A, Hobday M. The business of projects. Cambridge: Cambridge University Press; 2005.

[77] Crawford LH, Hobbs JB, Turner JR. Project categorization systems: Aligning capability with strategy for better results. Newtown Square, Pennsylvania: Project Management Institute; 2005.

[78] Crawford LH, Pollack JB, England D. Uncovering the trends in project management: Journal emphases over the last 10 years. Int $\mathbf{J}$ Project Manage 2006;24:174-84.

[79] Crawford LH. Profiling the competent project manager. In: Slevin DP, Cleland DI, Pinto JK, editors. The frontiers of project management research. Newtown Square, Pennsylvania: Project Management Institute; 2002.

[80] Cooke-Davies TJ. Project Success. In: Morris PWG, Pinto JK, editors. The Wiley Guide to Managing Projects. Hoboken, NJ: John Wiley and Sons; 2004. p. 004.

[81] Engwall M. No project is an island: linking projects to history and context. Res Policy 2000;32:789-808.

[82] Söderlund J. On the broadening scope of the research on projects: A review and a model for analysis. Int J Project Manage 2004;22(8): 655-68. 